\title{
曲げを受ける曲線桁橋腹板の解析と設計に関する一研究*

\author{
A STUDY ON ANALYSIS AND DESIGN OF WEB PLATE IN CURVED \\ GIRDER BRIDGES SUBJECTED TO BENDING
}

\author{
中井 博** - 北田俊行*** . 大南亮一**** . 川井 正 ${ }^{* * * * * *}$ \\ By Hiroshi NAKAI, Toshiyuki KITADA, Ryoichi OHMINAMI and Tadashi KAWAI
}

\begin{abstract}
This paper presents a design method of the web slenderness ratio and the corresponding rigidity of longitudinal stiffeners in the curved plate girders. The elastic non-linear behaviors of the curved web panels with/without longitudinal stiffeners subjected to pure bending are inquired by means of analysis using the up-dated lagrangian and an isoparametric finite element method. Based upon these analysis, a required slenderness ratio of web panels is investigated by setting a limit state concerning the maximum out-of-plane deflections and bending stresses. In order to evaluate the strength of the longitudinal stiffeners in the ultimate limit state of curved web panel, a curved beam-column model is proposed, then a design method for the required relative stiffness of the stiffeners is, moreover, recomended by adopting interaction curve of this beam-column model.
\end{abstract}

\section{1. まえがき}

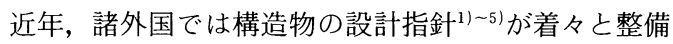
されており，限界状態設計や荷重係数設計法が取り入れ られてきている.このうち限界状態設計法では, 疲労限 界状態を除くと, 使用限界状態亡終局限界状態との 2 つ について十分に配慮した設計が行えるフォーマットが提 示されている.

わが国の直線桁橋の腹板の設計法では, 腹板の座屈強 度を使用限界とみなしている. そして, 座屈ののち終局 限界状態に至るまでの余剩耐荷力を見込み, 安全率を低 下させるという形で幅厚比規定が定められている.しか しながら, 曲線析腹板では, 曲率の影響により, 低荷重 段階から腹板に面外たわみが生じ, 荷重の増加に伴って このたわみも増大するため, 直線析と同様な設計法を踏

* 第 38 回土木学会年次学術講演会にて概要発表ずみ（昭 和 58 年 10 月)

** 正会員 工博 大阪市立大学教授 工学部土木工学科 ( ₹558 大阪市住吉区杉本 3-3-138)

*** 正会員 工博 大阪市立大学助教授 工学部土木工学 科 (同上)

**** 正会員 工修 川崎重工業株式会社技術研究所 ( 7673 明石市川崎町 1-1)

***** 学生会員 大阪市立大学大学院 工学研究科 修士課 程在学中
襲することは現実的でないように思う.

ところで, 純曲げを受ける曲線桁腹板に関する研究 に着目すればこれまでにCulver·Dym·Brogan ${ }^{6}$ およ び Culver·Dym·Uddin ${ }^{7)} ら$ 簡易腹板モデルを用いた 研究, Abdel-Sayed ${ }^{9)}$ による座屈固有值解析, Dabrowski·Wachowiak ${ }^{8)}$ ，三上・古西・米沢10),11) およ び倉西・樋渡 ${ }^{12}$, 13)なよ゙, 腹板の幾何学的非線形挙動まで も考慮した研究が挙げられる. 実験的研究としては, ア メリカ合衆国のCURT (大学研究チーム) による研究 が著名である.これらの研究成果のうち, 特に文献 14) の成果は, AASHTO ${ }^{15)}$ の曲線 I 析に関する設計法に反 映されている．ところが，この設計法は，文献 6)，7） の簡易腹板モデルに基づくものであるため, かなり安全 側に規定がつくられており，検討すべき点もあると考え る. また, 中井・北田・大南 ${ }^{16)}$ による実験的研究では曲 線桁模型による曲げ座屈と崩壊挙動が考察されている が, これらの研究は耐荷力に主眼をおいた基礎的な研究 であり，曲線桁腹板の設計法を提案するまでには至って いない.

本研究では, 以上の諸点にかんがみ, 設計上の曲率以 外に初期たわみも有する曲線析腹板の非線形弾性挙動 を, アイソパラメトリック・シェル要素を用いた有限要 素法 ${ }^{17), 18)}$ で解析する手法をまず述べる，そして，実橋 ${ }^{19)}$ 
を再現するような構造寸法および境界条件を有する解析 モデルについてパラメトリック計算を行い, 曲線桁腹板 に生ずる応力・たわみなどの変動特性を調べる. 次に, これらの計算結果をもとに，曲線㮏腹板の応力やたわみ についてある制限, すなわち限界值を設定し，それらに 対応する腹板の必要幅厚比を提案する. さらに，フラン ジが降伏に至っても水平補剛材が十分な強度を有するた めの条件について調べる. そのため, 水平補剛材とそれ に協力する腹板とで構成された $\mathrm{T}$ 字形断面のはり一柱モ デルを, Perry-Robertson の考えに基づいて強度解析す る. そして，この強度に見合うための剛度を軸方向圧縮 力と曲げを受けるはり-柱の相関曲線から調べ, 最後に 水平補剛材の必要剛度に関する設計式を提案する.

\section{2. 解析手法および腹板解析モデルに対する妥 当性の検討}

\section{(1) 解析手法}

曲線桁腹板の種々なパラメーターによる静的変動特性 を定量的に調べるため, 有限変位理論に基づいた有限要 素法を用いて解析を行った.

この解析では, 曲線析腹板が複雑な初期形状をもつこ とを考慮し，任意形状のシェル構造解析に適した Fig. 1 に示す 8 節点のアイソパラメトリック・シェル要素 ${ }^{17)}$ 用いた。 また，非線形性に対処するための有限変位解析 は, Updated Lagrangian 法 $^{18)}$ による増分理論に基づい て定式化した。開発したプログラムの精度は, 正解の与

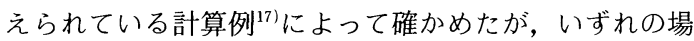
合にも十分な精度が得られた. Fig. 2 には, 本文で用い たプログラムのフローチャートを示す.

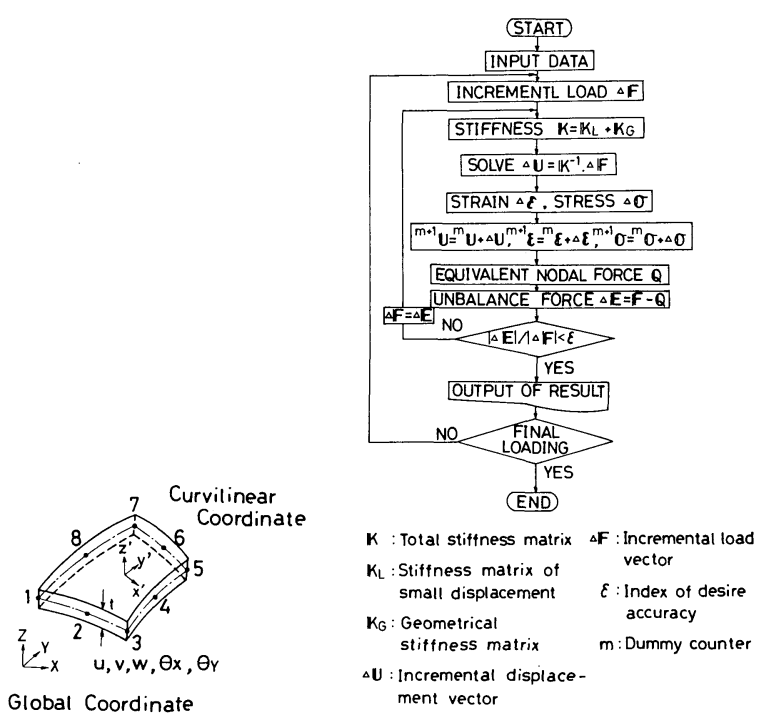

Fig. 1 Isoparametric Element.

\section{（2）腹板解析モデルに対する妥当性の検討}

a) フランジ辺の境界条件の影響

フランジと垂直補剛材とで区切られた腹板パネルを, Fig. 3 に示すような 3 種類の境界条件を有する解析モデ ルとして理想化した。すなわち，

(1) 腹板パネルのみのモデル

Case 1 ; フランジ辺の境界条件が単純支持 (S.S.)

Case 2 ; フランジ辺の境界条件が固定支持 (F.S.)

(2) フランジを有するI桁モデル

Case 3 ; 上下同一のフランジによる弾性支持 (E.S.)

各モデルの垂直補剛材位置における境界条件は，すべ て単純支持とした。 また, 載荷辺 $\overline{\mathrm{AB}}, \overline{\mathrm{CD}}$ は平面を保 つものと仮定し，断面回転角 $\theta$ と円周方向の剛体変位 $\bar{u}$ との自由度を有する剛棒を載荷辺に取り付け, 断面回 転角 $\theta$ を強制変位として与えて純曲げ状態を再現した. この場合, 実際の挙動之合致させるため, 載荷辺の円周

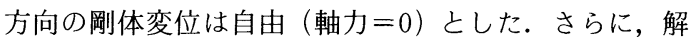
析モデルの対称性からその半分を取り出した. フランジ を有するモデルでは，腹板と同様な剛棒を載荷辺に取り 付け，面内回転角によりそり応力が与えられるようにし た. そして, 解析精度の検討を行ったのち, 最終的に腹 板パネルは $3 \times 6$, 上下フランジはそれぞれ $3 \times 2$ の要素 に分割した。

Fig. 4 は, 荷重の増加に伴う腹板の最大面外たわみ $\delta_{\max }$ の変化を示したものである. 同図において, 作用 曲げモーメント $M$ は, 初等はり理論に基づく腹板の初 期降伏曲げモーメント $M_{y}$ により無次元化されている.

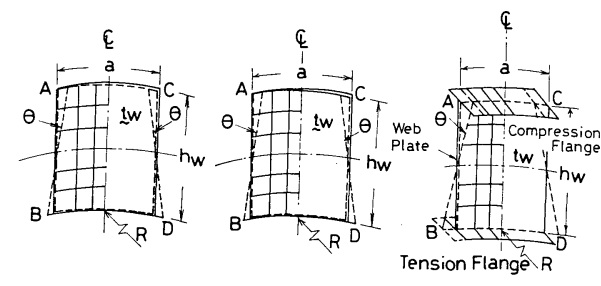

$\begin{array}{lll}\text { (a) Casel; Simple } & \text { (b) Case } 2 \text {; Fixed } & \text { (c) Case } 3 \text {; with } \\ \text { Supported Model } & \text { Supported Model } & \text { Flange Model }\end{array}$

Fig. 3 Analytical Model of Web Plate.

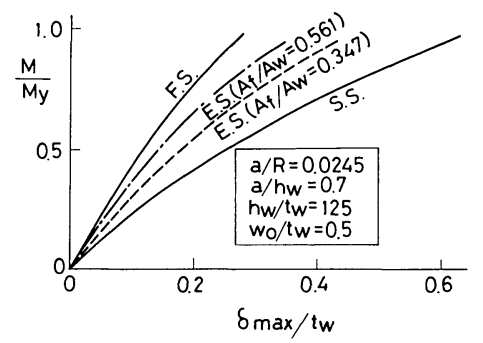

Fig. 4 Relationship between $M / M_{y}$ and $\delta_{\max } / t_{w}$. 
また， $A_{f} / A_{w}$ は，フランジと腹板との断面積比である. なお， $w_{0}$ は半波長の 2 重正弦波形により与えた腹板の 最大初期たわみ量である.

次に, 腹板の中央断面における橋軸方向の直応力度 $\sigma_{m}$ の分布, および, 桁深さ方向の面外曲げ応力度 $\sigma_{b m}$ の分布を，それぞれ Fig.5 (a)，(b) に示す. 同図では， 最大直応力度（圧縮フランジとの接合点に発生）が SS 41 材の公称降伏点 $\sigma_{y}=2400 \mathrm{~kg} / \mathrm{cm}^{2} \quad(235.2 \mathrm{MPa})$ に 達する場合の応力分布がプロットされている.このとき， 腹板が受け持つ抵抗モーメントを $M_{w e}$, 桁全体の抵抗 モーメントを $M_{e}$ と表わすことにする.

以上の計算結果から，各境界条件に対する $\delta_{\max }, M_{w e}$ および圧縮フランジと腹板との接合点における面外曲げ 応力度 $\sigma_{b m}$ の值を, 固定支持 (F.S.) の值を 1.0 とし た比の形でまとめると, Table 1 が得られる.なお, $\delta_{\max }$ も腹板が受け持つ抵抗モーメントが $M_{w e}$ に等しく なるときの值で比較している.この表より, $\delta_{\max }$ の值は, F.S. に比べて S.S. では 2 倍程度大きく，また $\sigma_{b m}$ の 值は, S.S. の場合にはもちろん 0 となるが，フランジ を有する E. S. の場合には F.S. に近い値となっている. さらに, Fig.5 (a) の直応力分布から明らかなように, 腹板の受け持つ抵抗モ一メント $M_{w e}$ は, はり理論によ る値より減少し, S.S. の場合には F.S. に比較し約 $20 \%$ も低下する。これらの計算結果を総合的に判断す ると, パラメトリック解析においては, 腹板の変位およ

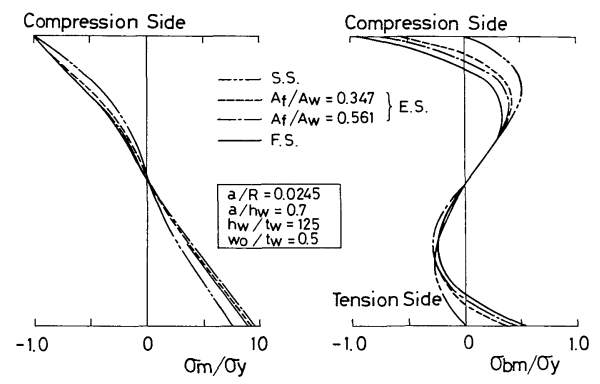

(a) Longitudinal Normal Stress (b) Transverse Out-of-plane Bending Stress

Fig. 5 Stress Distribution in Web Plate.

Table 1 Influence of Boundary Condition.

\begin{tabular}{|c|c|c|c|c|}
\hline \multirow{2}{*}{ Item } & \multirow{2}{*}{ S.S. } & \multirow{2}{*}{ F.S. } & \multicolumn{2}{|c|}{ E.S. } \\
\hline & & & $A_{f} / A_{w}=0.347$ & $A_{f} / A_{v}=0.561$ \\
\hline $\begin{array}{l}\text { Maximum } \\
\text { Out-of-Plane } \frac{\delta_{\max }}{\tau_{\mathrm{w}}} \\
\text { Deflection }\end{array}$ & 1.0 & 0.524 & 0.830 & 0.693 \\
\hline $\begin{array}{ll}\begin{array}{l}\text { Resisting } \\
\text { Bending } \\
\text { Moment }\end{array} & \frac{\mathrm{M}_{\mathrm{we}}}{\mathrm{M}_{\mathrm{wy}}}\end{array}$ & 0.833 & 1.0 & 0.919 & 0.906 \\
\hline $\begin{array}{l}\text { Maximum } \\
\text { Bending } \\
\text { Stress }\end{array} \quad \frac{\sigma_{\mathrm{bm}}}{\sigma_{\mathrm{y}}}$ & 0.0 & 1.0 & 0.825 & 0.699 \\
\hline
\end{tabular}

び応力が, 実際の曲線桁の挙動に近いと考えられるフラ ンジを考慮したCase 3 (Fig. 3 (c)) のモデルを用いる ほうがよいことがわかる.

b）曲率によるフランジのそり応力の影響

曲線プレートガーダーのフランジには，曲げによる垂 直応力 $\sigma_{b f}$ と同時に, フランジの曲率による局部曲げ応 力 $\sigma_{\omega}$ も発生する. 応力 $\sigma_{\omega}$ 之垂直応力 $\sigma_{b s}$ との比 $\zeta$ は, 次式により近似することができる.

$$
\zeta= \pm k\left(L^{2} / R W_{f}\right)\left(A_{f}+A_{w} / 6\right) \cdots
$$

ここに，L：フランジ固定点間距離, $W_{f}$ ：フランジの 鉛直軸まわりの断面係数, $k=0.106$ ：無限連続桁の曲 げモーメントを求めるための係数 ${ }^{20)}$.

実績調査結果 ${ }^{19)}$ を再整理すると, 実橋のとはー0.5〜 0.5 の範囲内に分布しているため, $\zeta=-0.5,0$ および 0.5 とした場合の解析を行った. Fig. 6 は腹板とフラン ジとにおける橋軸方向の直応力度の分布, また Fig. 7 は 作用曲げモーメント $M$ と腹板の最大曲げ応力度 $\sigma_{b m}$ と の関係を示したものである.

これらの図から， $M$ が $M_{e}$ 以下の範囲では, 腹板の 垂直応力および面外曲げ応力は，フランジの曲率による 局部曲げ応力の影響をほとんど受けないことがわかる.

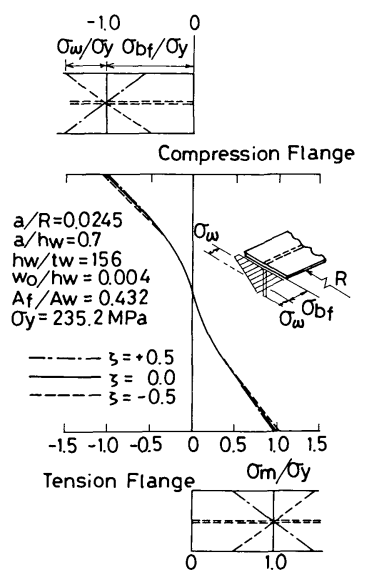

Fig. 6 Influence of Warping Stress in Flange Plate on Longitudinal Normal Stress Distribution.

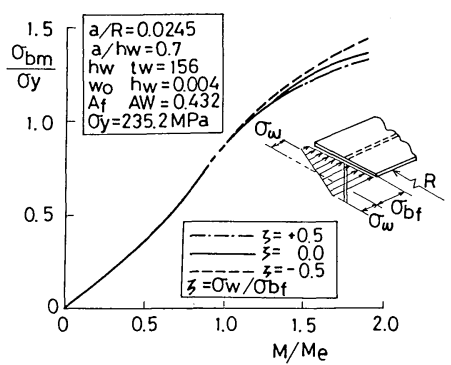

Fig. $7 \sigma_{b m} / \sigma_{y}$ and $M / M_{e}$ Curves for Warping Stress in Flange Plate. 
したがって, 以下の解析ではこの応力を無視することに する.

c）腹板の初期たわみの影響

実橋における腹板では, 垂直補剛材あるいは水平補剛 材の溶接取付面の差異により，初期たわみ形状が異なる ことが明らかにされている16)。この初期たわみ形状の差 異が，桁の抵抗モーメント $M_{e}$ に与える影響を調べる.

まず，水平補剛材のない腹板では，最大たわみが曲率 中心の内側 (鞍状) および外側（樽状）となる半波長の 2 重正弦波形により初期たわみを与えた。また，初期た わみの最大值 $w_{0}$ は, 道路橋示方書 ${ }^{21}$ （以下，JSHB と よぶ）の許容初期たわみ量 $w_{0}=h_{w} / 250$ を適用した.

Fig. 8 は，上記の初期たわみモードに対する析の抵抗 モーメント $M_{e}$ の変化を示したものである. 同図より, 鞍状の初期たわみの場合, 初期たわみのない場合に比べ かえって $M_{e} / M_{y}$ が上昇し, 樽状の場合, 最も $M_{e} / M_{y}$ が低下することがわかる.

次に, 水平補剛材を 1 段用いる腹板については, 実測 結果 ${ }^{16)}$ を参考にして, Table 2 に示す $\mathrm{A} \sim \mathrm{F}$ の合計 6 夕 イプの初期たわみを有するモデルについて解析した. 同 表の $A_{s}$ は, 水平補剛材の断面積である. 解析結果, 同 表に示すように, Fタイプのモデルの抵抗モーメント $M_{e}$ が最小となった.

水平補剛材を 2 段有する場合についても同様な解析を 行った. その結果, 水平補剛材のない場合と同様に, 腹

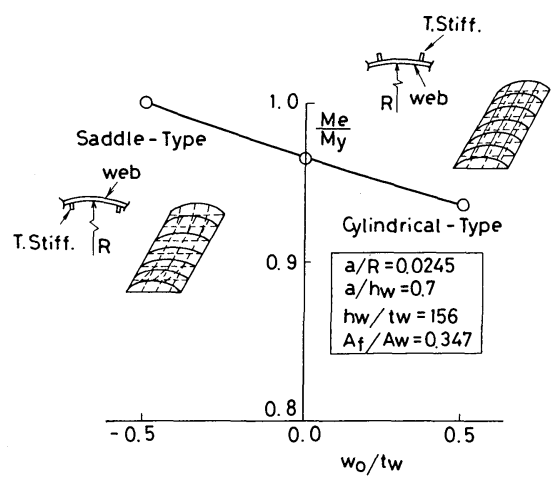

Fig. 8 Sensitivity of Initial Deflection of Web Plate to Resistance Bending Moment.

Table 2 Variations of $M_{e} / M_{y}$ due to Initial Deflection Modes $\left(a / R=0.0245, a / h_{w}=0.7, h_{w} / t_{w}=233, A_{f} / A_{w}=\right.$ $\left.0.647, A_{s} / A_{w}=0.048\right)$.

\begin{tabular}{|c|c|c|c|c|c|c|}
\hline TYPE & $A$ & $B$ & C & $D$ & $E$ & $F$ \\
\hline $\begin{array}{l}\text { Initial } \\
\text { Deflec- } \\
\text { tion Mode }\end{array}$ & 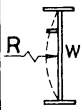 & Rv到 & 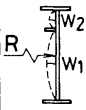 & $R_{\gamma}=$ & 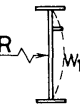 & $\mathbb{H}^{\prime}$ \\
\hline $\mathrm{Me} / \mathrm{My}$ & 0.987 & 0.986 & 0.984 & 0.963 & 0.963 & 0.957 \\
\hline
\end{tabular}

板全体が曲率中心の外側にたわむ樽状の初期たわみモ一 ドに対する抵抗モーメント $M_{e}$ が最小となった.

\section{3. パラメトリック解析による曲線桁腹板の弾 性挙動}

\section{（1） 解析パラメーター}

ここでは，実橋を対象として，水平補剛材が 2 段まで の曲線桁腹板についてのパラメトリック解析を行った.

水平補剛材を有する腹板では，Fig. 3 (c) の要素分割 をさらに細かくし，水平補剛材の取付位置に節点を設け た.そして, 水平補剛材も要素分割して解析した.その際, 腹板解析モデルの境界条件は, Fig. 3 (c) の Case 3 とし, 載荷条件は, フランジのそり応力を無視した純曲げ載荷 とした。また，初期たわみ形状としては，すべて曲率中 心の外側にたわむ樽状とした.そして, 解析パラメーター

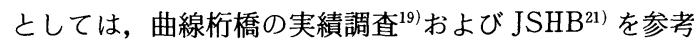
に Table 3 に示す $a / R, h_{w} / t_{w}$ および $A_{f} / A_{w}$ を抽出し, 合計 60 ケースの組合せを考えた. また，鋼材としては， SS 41 材 (公称降伏点 $\sigma_{y}=2400 \mathrm{~kg} / \mathrm{cm}^{2}(235.2 \mathrm{MPa})$ ) および SM $50 \mathrm{Y}$ 材（公称降伏点 $\sigma_{y}=3600 \mathrm{~kg} / \mathrm{cm}^{2}$ $(352.8 \mathrm{MPa}))$ を対象とした.

\section{（2）パラメトリック解析結果とその考察}

a) 抵抗モーメント特性

Fig. 9 は, 腹板の橋軸方向の最大曲げ応力度 $\sigma_{m}$ が公

Table 3 Curvature Parameter $a / R$ and Slenderness Ratio $h_{w} / t_{w}$

\begin{tabular}{|c|c|c|c|}
\hline $\begin{array}{l}\text { Number } \\
\quad \text { of } \\
\text { L.Stiff. }\end{array}$ & \multicolumn{2}{|c|}{$\begin{array}{l}\text { Combinations of Curvature } \\
\text { Parameter a/R and Slenderness } \\
\text { Ratio } \hat{h}_{w} / t_{w}\end{array}$} & $\begin{array}{l}\text { Ratio } \\
A_{f} / A_{w}\end{array}$ \\
\hline \multirow{2}{*}{0} & $a / R$ & $\begin{array}{llll}0.0 & 0.0098 & 0.0245 & 0.049\end{array}$ & \multirow{2}{*}{$0.449 \sim 0.698$} \\
\hline & $h_{w} / t_{w v}$ & $100 \quad 112 \quad 125 \quad 140 \quad 156$ & \\
\hline \multirow{2}{*}{1} & $a / R$ & $\begin{array}{llll}0.0 & 0.0098 & 0.0245 & 0.049\end{array}$ & \multirow{2}{*}{$0.250 \sim 0.722$} \\
\hline & $\mathrm{h}_{\mathrm{w}} / \mathrm{t}_{\mathrm{w}}$ & $90 \quad 120 \quad 150 \quad 210 \quad 233 \quad 260$ & \\
\hline \multirow{2}{*}{2} & $\dot{a} / R$ & $\begin{array}{llll}0.0 & 0.0098 & 0.0245 & 0.049\end{array}$ & \multirow{2}{*}{$0.467 \sim 1.113$} \\
\hline & $h_{w} / t_{w}$ & $130 \quad 190 \quad 250 \quad 310$ & \\
\hline
\end{tabular}
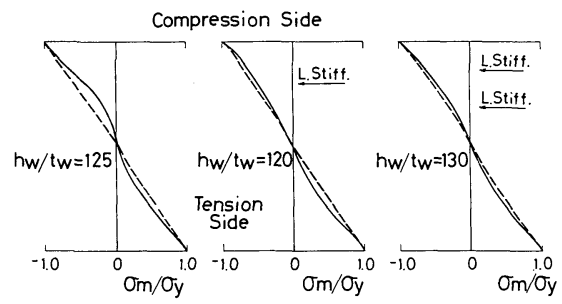

(a) Without L.Stiff. (b) With one L.Stiff. (c) With two L.Stiff. $a / R=0.049$ --- $a / R=0$

Fig. 9 Longitudinal Normal Stress Distribution $\left(a / h_{w}=0.7\right.$, $\left.w_{0} / h_{w}=0.004, \sigma_{y}=235.2 \mathrm{MPa}\right)$. 
称降伏点 $\sigma_{y}$ に達するときの分布図を示したものである. このときの抵抗モーメント $M_{e}$ を析の降伏モーメント $M_{y}$ で無次元化し, $M_{e} / M_{y}$ 值を垂直補剛材間隔と曲率半 径との比 $a / R$ および幅厚比 $h_{w} / t_{w}$ についてプロットし たものが Fig. 10 である.

水平補剛材の有無にかかわらず, $M_{e} / M_{y}$ 值は $h_{w} / t_{w}$ の影響をほとんど受けずほぼ一定となる。また， $a / R$ の増大に伴って, $M_{e} / M_{y}$ 值は低下するが, 実橋の $a / R$ の使用範囲内では $M_{e} / M_{y}$ が 0.9 より小さくなることは ない.これは，作用モーメントがほとんどフランジで受 け持たれ，腹板の分担モーメントが小さいためであると 考えられる.

b) 面外たわみ特性

同様に作用モーメント $M$ が抵抗モーメント $M_{e}$ にな るときの面外たわみを, Fig. 11 に示す.

この図から, 水平補剛材のない場合, 圧縮側の腹板で 最大面外たわみ $\delta_{\text {max }}$ が生じ, その位置は $0.25 h_{w}$ 付近 である. JSHB による位置 $b=0.2 h_{w}$, あるいは, $b_{1}=$ $0.14 h_{w}$ および $b_{2}=0.32 h_{w}$ に水平補剛材をそれぞれ 1 本および 2 本入れると, この変位は効果的に止められる ことがわかる.

Fig. 12 は, 水平補剛材のない場合の $\delta_{\text {max }}$ の $a / R$ お よび $h_{w} / t_{w}$ による変動を例示したものである. 一般に, $h_{w} / t_{w}$ が大きいほ亡゙, また $a / R$ が大きいほど $\delta_{\max }$ は 大きくなる傾向をもつ.

c）面外曲げ応力特性

全く同様にモデルの載荷辺における反力から算定され

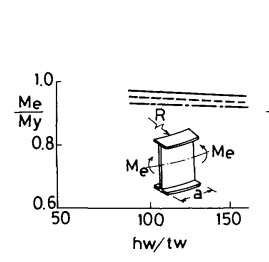

(a) Without L.Stiff.

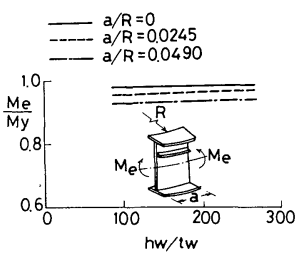

(b) With one L.Stiff.

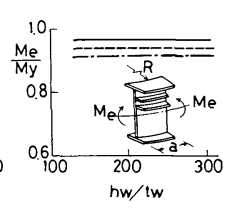

(c) With two L.Stiff.
Fig. 10 Variations of $M_{e} / M_{y}$ due to $h_{w} / t_{w}$ and $a / R$ Compression Flange

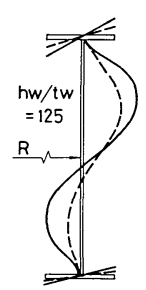

(a) Without

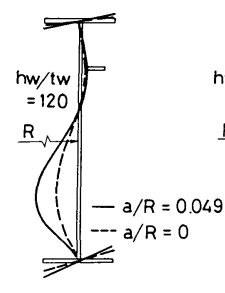

Tension Flange

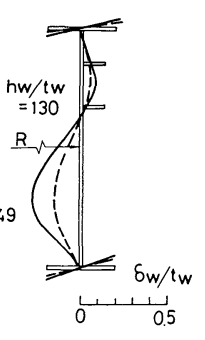
(c) With two
L. Stiff.
(b) With one
L. Stiff.

Fig. 11 Out-of-Plane Deflection of Web Plate $\left(a / h_{w}=\right.$ $\left.0.7, w_{0} / h_{w}=0.004, \sigma_{y}=235.2 \mathrm{MPa}\right)$.
る作用モーメント $M$ が抵抗モーメント $M_{e}$ になるとき の水平補剛材のない腹板における桁深さ方向の面外曲げ 応力 $\sigma_{b m}$ は, Fig.13 (a) に示す分布をし, その最大值 は腹板と圧縮フランジとの接合点に生じることがわか る. また，水平補剛材を有する腹板の場合には，Fig. 13 (b)，（c）に示す分布を呈する. 水平補剛材剛度は, JSHB の必要最小剛比に対する值になるようにした.

これらの図より，水平補剛材が腹板の面外たわみを拘 束するために，それらの位置における面外曲げ応力分布 は, 連続析の橋軸方向の支点上近傍における曲げ応力分 布と類似し; 面外曲げ応力度の最大は, 引張フランジと の接合点に生じることがわかる.

最大面外曲げ応力 $\sigma_{b m}$ を $\sigma_{y}$ で無次元化し, $\sigma_{b m} / \sigma_{y}$ と $a / R$ および幅厚比 $h_{w} / t_{w}$ との関係をプロットすると, Fig. 14 が得られる.

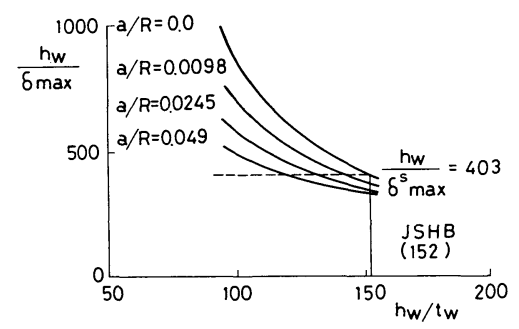

Fig. $12 h_{w} / \delta_{\max }-h_{w} / t_{w}$ Curves for Curvature Parameter $a / R$ (Without L. Stiffener : $\sigma_{y}=235.2 \mathrm{MPa}$ ).

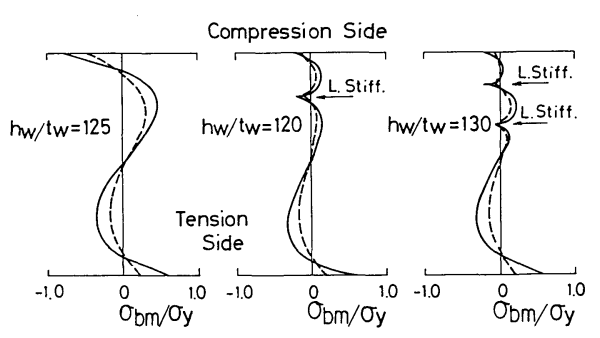

(a) Without L.Stiff. (b) With one L.Stiff. (c) With two L.Stiff. $\begin{aligned}-a / R & =0.049 \\ a / R & =0\end{aligned}$

Fig. 13 Transverse Out-of-Plane Bending Stress Distribution $\left(a / h_{w}=0.7, w_{0} / h_{w}=0.004, \sigma_{y}=235.2 \mathrm{MPa}\right)$.

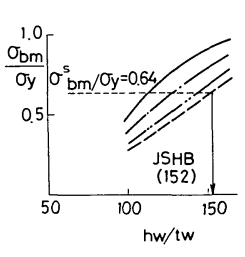

(a) Without L.Stiff.

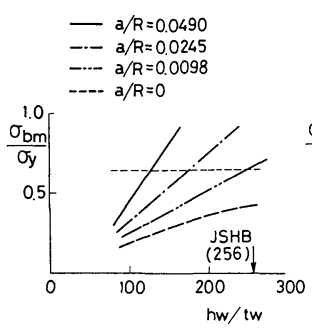

(b) With one L.Stiff

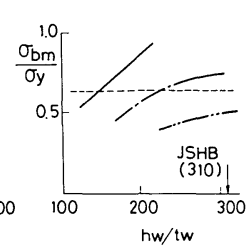

(c) With two L.Stiff.

Fig. $14 \sigma_{b m} / \sigma_{y}-h_{w} / t_{w}$ Curve for Curvature Parameter $a / R$ $\left(\sigma_{y}=235.2 \mathrm{MPa}\right)$. 
いずれの場合にも， $a / R$ が大きくなるほよ゙，また $h_{w} / t_{w}$ が大きくなるほど $\sigma_{b m} / \sigma_{y}$ は大きくなる.

\section{4. 腹板の必要幅厚比に関する一提案}

\section{（1）腹板の面外曲げ㐫力とたわみとの限界值}

曲線桁腹板では低荷重段階から面外たわみが進み, 顕 著な座屈現象がみられないため, 直線桁と同じ方法で必 要幅厚比を決定することができない。ここでは，腹板の たわみ，あるいは，応力に着目した限界値を設定し，そ れをもとに必要幅厚比を検討する.

その規準としては， $a / R$ を 0 とした JSHB の直線桁 腹板厚規定に従うこととした。 そして，その規準による 限界幅厚比で設計された直線桁腹板（もちろん初期たわ みを有する一種のシェル）に発生する最大面外たわみ $\delta_{\text {max }}^{s}$ と最大面外曲げ応力 $\sigma_{\max }^{s}$ とを求め, 曲線桁腹板の 面外たわみ $\delta_{\text {max }}^{c}$ と面外曲げ応力 $\sigma_{b m}^{c}$ とが, 上記以内の 值に納まるような限界値を定めることとした.すなわち,

$$
\delta_{\max }^{c} \leqq \delta_{\max }^{s}, \sigma_{b m}^{c} \leqq \sigma_{b m}^{s} .
$$

特に, 応力 $\sigma_{b m}^{s}$ としては, 最近, 直線析腹板の面外 曲げに伴う疲労強度としてとらえる研究も活発である が22,23), 直線析のこれまでの健全性の実績を踏まえ ${ }^{24), 25)}$, とりあえず上述のように設定することとした．疲労強度 の具体的な值が提示されれば，それに従って検討するこ ともできると考える.

\section{（2）幅厚比と曲率パラメーターとの関係}

Fig. 14 の点線は, JSHB の限界幅厚比を有する直線 析腹板に生じる最大面外曲げ応力度 $\left(\sigma_{b m}^{s} / \sigma_{y}=0.64\right)$ から求められる曲線析腹板の面外曲げ応力の限界值を示 したもので, 同図の点線と実線との交点が式 $(2 \cdot b)$ の 等号の条件を満足する。これらの交点に対応した $h_{w} / t_{w}$ の值が, 曲線桁腹板の必要幅厚比とすることが できる.

同様に, Fig. 12 におけるたわみに関する限界値 (点線) から必要幅厚比を規定することができる.

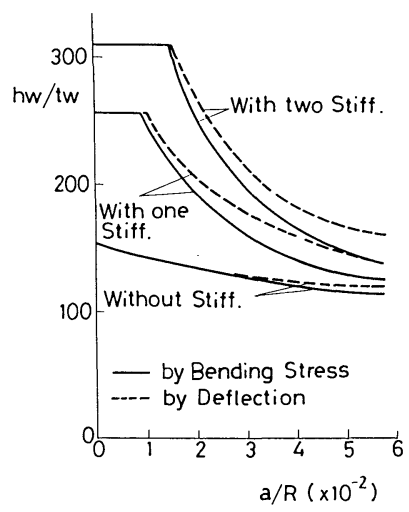

Fig. $15 h_{w} / t_{w}-a / R$ Curves for Curved Web Panel (SS 41).
以上のようにしてパラメトリック解析結果を整理する と, Fig. 15 に例示するような $h_{w} / t_{w}$ と $a / R$ との関係が 得られる。

\section{（3）最大面外曲げ応力とたわみとの関係}

$\sigma_{b m}^{s}$ が生じるときの最大面外たわみ $\delta_{\max }$ を求め, $h_{w} / \delta_{\max }$ と $a / R$ との関係をプロットすると, Fig. 16 が 得られる. 同図から $a / R$ が変化しても, $h_{w} / \delta_{\max }$ の值 はほとんど一定であることがわかる。したがって， $a / R$ の值にかかわらず一定の面外たわみの限界值（た とえば, フランジの公称降伏点 $\sigma_{y}=2400 \mathrm{~kg} / \mathrm{cm}^{2}$ $(235.2 \mathrm{MPa})$ の場合， $h_{w} / \delta_{\max } \cong 400 ）$ を設定すれば, 面外曲げ応力の限界值を設定した場合とほぼ同じ結果が 得られることになる.

また，同図において，各曲線に対する $h_{w} / \delta_{\max }$ の值 が $a / R=0$ (直線桁) の值よりわずかに大きくなってい る.この場合には，曲げ応力を限界値とした方が厳しい 条件となる. Fig. 15 においても，たわみの限界値に基 づいた必要最大幅厚比の曲線の方が，曲げ応力に基づい た値より大きいことを示している.

\section{（4）必要幅厚比に関する設計式の提案}

最大面外たわみ，あるいは，曲げ応力に限界值を設け ることにより, 曲線桁腹板の必要最大幅厚比の値を求め ることができる，その際，最大曲げ応力を限界値とした 場合の方が安全側の設計となるので, 最終的な $h_{w} / t_{w}$ と $a / R$ との関係をプロットすると, Fig. 17 に示すよう になる。なお，Fig.17 (a) 中には，参考のため

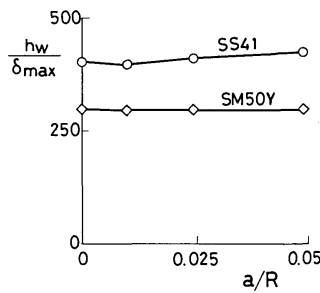

(a) Without L.Stiff.

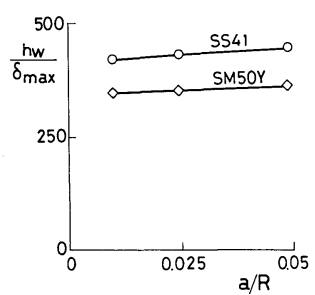

(b) With one L.Stiff.
Fig. 16 Relationship between Maximum Deflection and Maximum Bending Stress.

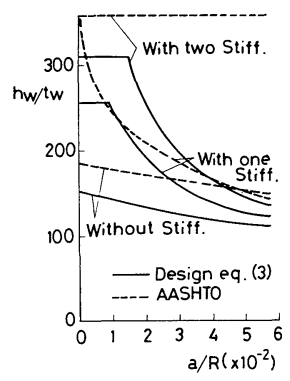

(a) SS 41

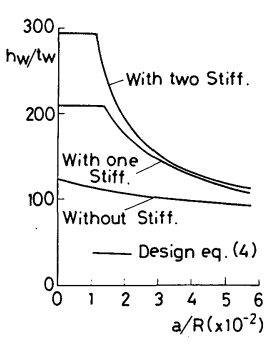

(b) SM 50Y
Fig. 17 Proposed Slenderness Ratio for Curved Web Panel. 


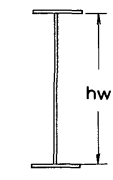

(a) Without L.Stiff.

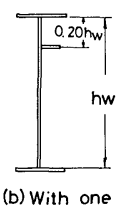

L.Stiff.

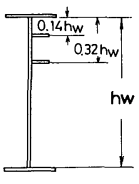

(c) With two
Fig. 18 Location of Longitudinal Stiffener.

AASHTO ${ }^{15)}$ の設計曲線も併記してある.

これらの図で表わされる設計曲線を最小二乗法により 回帰すれば, 次式を得る.

a) SS 41 材相当 $\left(\sigma_{y}=2400 \mathrm{~kg} / \mathrm{cm}^{2}(235.2 \mathrm{MPa})\right)$ 水平補剛材のない場合;

$$
h_{w} / t_{w}=22.95 /(a / R+0.151)
$$

水平補剛材を 1 段用いる場合;

$$
\left.\begin{array}{rl}
h_{w} / t_{w}=256, & (a / R \leqq 0.009) \\
= & 256\left[1.232-29.82(a / R)+303.7(a / R)^{2}\right], \\
(a / R>0.009)
\end{array}\right\}
$$

水平補剛材を 2 段用いる場合;

$$
\left.\begin{array}{rr}
h_{w} / t_{w}=310, \quad(a / R \leqq 0.015) \\
=310\left[1.643-51.19(a / R)+556.8(a / R)^{2}\right], \\
(a / R>0.015)
\end{array}\right)
$$

b) $\mathrm{SM} 50 \mathrm{Y}$ 材相当 $\left(\sigma_{y}=3600 \mathrm{~kg} / \mathrm{cm}^{2}(352.8 \mathrm{MPa})\right)$ 水平補剛材のない場合;

$h_{w} / t_{w}=26.67 /(a / R+0.218)$

水平補剛材を 1 段用いる場合;

$$
\begin{aligned}
& h_{w} / t_{w}=209,(a / R \leqq 0.014) \\
&= 209\left[1.748-55.17(a / R)+631.0(a / R)^{2}\right], \\
&(a / R>0.014)
\end{aligned}
$$

水平補剛材を 2 段用いる場合;

$$
\left.\begin{array}{r}
h_{w} / t_{w}=294, \quad(a / R \leqq 0.011) \\
=294\left[1.510-53.20(a / R)+625.6(a / R)^{2}\right], \\
(a / R>0.011)
\end{array}\right)
$$

これらの式で, 水平補剛材の取付位置は, 前述の腹板 の面外たわみ (Fig.11) と面外曲げ応力（Fig.13）とを 参照し, 特に厳密な解析を行わないとき, Fig. 18 に示 すように直線析と同じとした。

\section{5. 水平補剛材の必要剛度に関する提案}

\section{（1）水平補剛材のモデル化}

曲線桁腹板における水平補剛材は, フランジが降伏に 至っても十分な強度を有するように設計する必要があ る. このとき, 腹板の水平補剛材が受ける外力は, その 取付位置に生じる腹板の橋軸方向の直応力から推定され る.

したがって，水平補剛材を Fig. 19 に示すような曲率

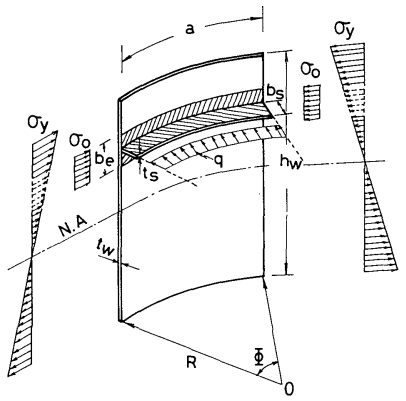

Fig. 19 Forces Acting on Longitudinal Stiffener.

を有し，腹板の有効幅をもつ T 形断面のはり-柱モデル に置換できるものと仮定する.すると，はり-柱モデル は橋軸方向の圧縮力 $P$ と曲率による半径方向の等分布 荷重 $q$, すなわち $A_{w e}$ を腹板の有効断面 $\left(A_{w e}=b_{e} \cdot t_{w}\right)$, $\psi$ を水平補剛材の位置を表わす係数 $(=0.6)$ とすると,

$$
P=\psi \cdot \sigma_{y} \cdot A_{w e}, \quad q=P / R \cdots \cdots \cdots \cdots \cdots \cdots \cdot(5 \cdot \mathrm{a}, \mathrm{b})
$$

を受けることになる．また，有効幅 $b_{e}$ は，曲げを受け る幅広フランジの有効幅を適用すると，次式で表わされ $3^{26)}$.

$$
b_{e}=t_{s}+0.181 \cdot a
$$

ここに, $t_{s}$ : 水平補剛材の板厚, $a$ : 垂直補剛材間隔.

垂直補剛材位置で連続した水平補剛材を対象とし，そ のはりー柱モデルを Fig. 20 に示す.はり-柱モデルの両 端は，回転に対して固定支持と考えられる.したがって， 両端では,

$$
\left.M_{0}=q R^{2}(2 / \Phi) \cdot \tan (\Phi / 2)-1\right\} \cdot
$$

なる固定モーメントが発生する.ここに， $\Phi$ : 垂直補剛 材間の中心角.

\section{（2）はり-柱モデルの断面力}

Fig. 20 に示したはり-柱モデルは，付加たわみの影響 を考慮して容易に解析できる．まず，初期たわみ $v_{0} を$

$$
v_{0}=\bar{v}_{0} \sin (\pi \phi / \Phi) \cdot
$$

と仮定し，たわみ $v$ を次式で近似する.

$$
v=\bar{v}\{1-\cos (2 \pi \phi / \Phi)\} \text {. }
$$

ここに, $\phi$ : はり一柱モデルの任意点における中心角.

すると，曲げモーメントのつり合いより，次の誤差関 数が得られる.

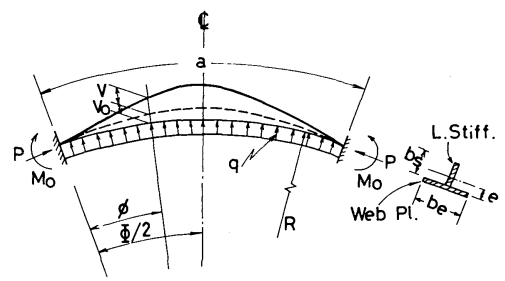

Fig. 20 Beam-Column Model with Curvature. 


$$
\begin{aligned}
\varepsilon(\phi)= & E I \frac{d^{2} v}{R^{2} d \phi^{2}}+q R^{2} \tan \frac{\Phi}{2} \sin \phi-q R^{2}(1-\cos \phi) \\
& +P\left(v+v_{0}+e\right)-M_{0} \cdots \cdots \cdots \ldots \ldots \ldots \ldots \ldots \ldots(10)
\end{aligned}
$$

ここに, $E I:$ はりの曲げ剛性, $R$ : 曲率半径, $e:$ 腹板 厚中央面から $\mathrm{T}$ 形断面の中立軸までの距離.

そこで, Galerkin 法を適用すると，

$\int_{0}^{\phi} \varepsilon(\phi)\{1-\cos (2 \pi \phi / \Phi)\} R d \phi=0 \cdots$

から，仮定たわみに対する最も適切な係数 $\bar{v}$ が求めら れる.すなわち,

$$
\begin{aligned}
\bar{v}= & \left\{4 q \Phi /\left(4 \pi^{2}-\Phi^{2}\right) \cdot \tan (\Phi / 2)+P\left(8 v_{0} / 3 \pi+e / \Phi\right)\right. \\
& \left.-M_{0} / \Phi\right\} /\left\{E I(2 \pi / R \Phi)^{2}-3 P\right\} \cdots \cdots \cdots \cdots \cdots \cdots(12)
\end{aligned}
$$

したがって，任意点における曲げモーメント $M_{s}$ は， $M_{s}=-E I\left(d^{2} v / R^{2} d \phi^{2}\right)$

から容易に求めることができる.

Fig. 21 は，水平補剛材の中央断面における軸ひずみ に関して, 曲線桁模型による実験值 ${ }^{27)}$ と上記のはり一柱 モデルによる計算値とを比較したものである. 同図では, 圧縮フランジの軸方向ひずみが降伏ひずみに達したとき の值が示されている. 同図から，はり-柱モデルによっ て水平補剛材の耐荷力を評価できることがわかる.

\section{（3）はり-柱モデルの耐荷力}

水平補剛材は, Fig. 22 に示すように, 曲率中心に対 して内側あるいは外側に取り付けられることがあり, そ れぞれに対して耐荷力が相違する.

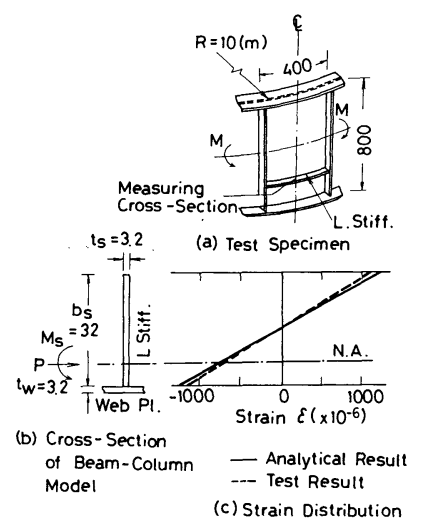

Fig. 21 Strain Distribution in Beam-Column.

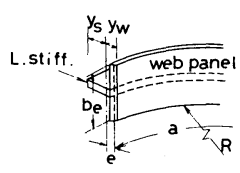

(a) Stiffener Attached on outer surface of Curved Web

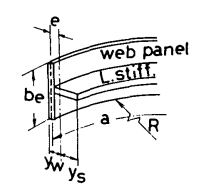

(b) Stiffener Attached on inner surface of Curved Web
Fig. 22 Location of Longitudinal Stiffener.
いまここれらに対する耐荷力を Perry-Robertson の考 え方に従い軸方向圧縮力 $P$ と曲げモーメント $M_{s}$ とを 受けるはり一柱の初期降伏線で評価すると, 式 (14) と Fig. 23 とに示す相関曲線が得られる.

$$
\left.\begin{array}{ll}
\text { 曲線(1) } & P / P_{y}-M / M_{y} \leqq 1 \\
\text { 曲線(2) } & P / P_{y}+\left(y_{w} / y_{s}\right)\left(M / M_{y}\right) \leqq 1 \\
\text { 曲線(3) } & -P / P_{y}+M / M_{y} \leqq 1
\end{array}\right\} \cdots(14 \cdot \mathrm{a} \sim \mathrm{c})
$$$$
\text { ここに, } M_{y} \text { : 降伏モーメント, } P_{y} \text { : 降伏軸圧縮力. }
$$

\section{（4）水平補剛材の必要剛比に関する提案}

上で示した相関曲線を用い，はり一柱モデルが降伏し ない条件から, 水平補剛材の必要剛比 $\gamma_{L}^{c}$, すなわち

$$
\gamma_{L}^{c}=E I_{n} / h_{w} D
$$

を算定することができる．ここに， $I_{n}$ ：その取付面まわ りの水平補剛材 1 本の断面二次モーメント, $D:$ 腹板の 曲げ剛度 $\left(=E \cdot t_{w}{ }^{3} / 12\left(1-\mu^{2}\right)\right)$.

実橋の曲線析腹板を対象としたパラメトリック解析を 通じて求められた必要剛比パラメーター $\beta_{L}$,

$$
\beta_{L}=\gamma_{L}^{c} / \gamma_{L}^{\mathrm{JSHB}} .
$$

と曲率パラメーター,

$$
Z=\left(a^{2} / R t_{w}\right) \sqrt{1-\mu^{2}} \text {. }
$$

との関係を Fig. 24 に示す.ここで， $\gamma_{L}^{\mathrm{JSHB}}$ は，JSHBで 定められている水平補剛材の必要剛比である.もちろん, パラメトリック解析を行う際の水平補剛材の板幅 $b_{s}$ 之 板厚 $t_{s}$ との值は, $\mathrm{JSHB}^{21)}$ の規定を満足するようにとっ た.そして, その取付位置は, 腹板の曲率中心内側ある いは外側のいずれか片側で, 圧縮フランジ側の端部から $0.2 h_{w}$ の距離とした.

Fig. 24 から, 水平補剛材の取付面が曲率中心の外側 にある場合は, 内側にある場合に比べ大きな剛比が必要

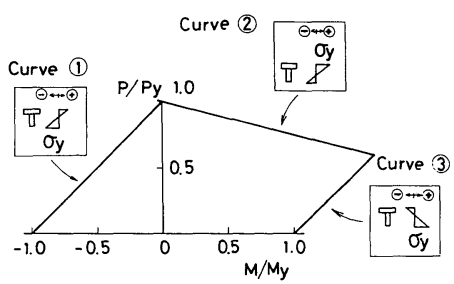

Fig. 23 Initial Yield Line for Beam-Column Model of Longitudinal Stiffener.

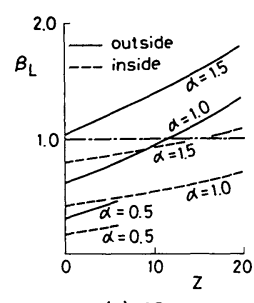

(a) $\mathrm{SS} 41$

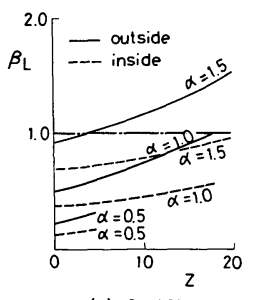

(b) SM50Y
Fig. 24 Variation of $\beta_{L}$ due to Curvature Parameter $Z$. 
Table 4 Coefficients $C_{1} \sim C_{4}$ in Equation (18).

\begin{tabular}{|c|c|c|c|c|c|}
\hline \multirow{2}{*}{$\begin{array}{c}\text { Steel } \\
\text { Grade }\end{array}$} & $\begin{array}{c}\text { Location } \\
\text { of } \\
\text { stiffener }\end{array}$ & $\begin{array}{c}C_{1} \\
\left(\times 10^{-4}\right)\end{array}$ & $\begin{array}{c}\mathrm{C}_{2} \\
\left(\times 10^{-2}\right)\end{array}$ & $C_{3}$ & $C_{4}$ \\
\hline \multirow{2}{*}{ SS 4I } & Outside & 3.766 & 3.226 & 0.739 & 0.108 \\
\cline { 2 - 6 } & Inside & 2.838 & 0.163 & 0.775 & 0.163 \\
\hline \multirow{2}{*}{ SM 50Y } & Outside & 5.362 & 1.549 & 0.818 & 0.227 \\
\cline { 2 - 6 } & Inside & 3.286 & -0.464 & 0.800 & 0.200 \\
\hline
\end{tabular}

とされる.また，アスペクト比 $\alpha$ と曲率パラメーター $Z$ 亡の組合せによって $\beta_{L}$ が 1.0 以下の值を取る場合が あるが,この場合には, $\beta_{L}=1.0$ とした方が安全側の設 計ができると考えられる.

同図の曲線に最小二乗法を適用し，必要剛比パラメー ター $\beta_{L}$ の設計式をまとめると，次式のようになる.

$$
\beta_{L}=\left(C_{1} Z+C_{2}\right) Z+C_{3} \alpha-C_{4} \geqq 1
$$

ここに, 係数 $C_{1} \sim C_{4}$ は, 補剛材の取付面および使用鋼 材の差異によって, Table 4 に示すような值をとる.

\section{6. ま と}

本文は，曲げを受ける曲線桁腹板パネルを，有限要素 法を用いて解析したものである．腹板の非線形弾性挙動 の多数のパラメトリック解析から曲線桁腹板に発生する 面外たわみ, および, 面外曲げ応力の限界值を設定した. そして, 直線桁橋の限界幅厚比に関する設計規準をべ一 スとし, この限界値に対応する腹板の必要幅厚比の設計 式を提案した. さらに，水平補剛材を軸方向圧縮力と曲 げモーメントとを受けるはり-柱モデルに置換し，断面 力を解析した．そして，Perry-Robertsonの方法を適用 してはり一柱の耐荷力に関する相関曲線を求め,それを 利用して, 水平補剛材の必要剛比の設計式も提案した.

謝辞：本研究は，文部省科学研究費，および阪神 高速道路公団の援助のもとに実施した. 関係各位に深謝 する. また，数值解析には，(株）川崎重工業の計算機 IBM 3033 を使用したことを付記する.

\section{参 考 文 献}

1) British Standards Institution : BS 5400 part 3, Code of practice for design of steel bridges, 1979.

2) Ravindra, M. K. and Galambos, T. V. : Load and Resistance Facter Design for Steel, Proc. of ASCE, ST 9, Vol. 104, pp. 1337 1353, Sept. 1978.

3) Yura, J.A., Galambos, T.V. and Ravindra, M. K. : The Bending Resistance of Steel Beams, Proc. of ASCE, ST 9, Vol. 104, pp. 1355 1370, Sept. 1978.

4) Deutsches Institut für Normung, 18800 , Teil $3:$ Stahlbaulen; Stabilitäts-fälle, Beulen von Platten, Jan. 1982.
5) Deutsher Ausschuß für Stahlbau, Beulsicherheitsnachweise für Platten, Richtlinie 012 (DAST Ri 012).

6) Culver, C. G., Dym, C. L. and Brogan, D. K. : Bending Behavior of Cylindrical Web Panel, Proc. of ASCE, ST 10, Vol. 98, pp. 2201 2308, Oct. 1972.

7) Culver, C.G., Dym, C.L. and Uddin, T. : Web Slenderness Requirement for Curved Girders, Proc. of ASCE, ST 3, Vol.99, pp.417 430, Mar. 1973.

8) Dabrowski, R. and Wachowiak, J. : Stress in Thin Cylindrical Webs of Curved Plate Girders, Proc. of Colloquium on design of Plate and Box Girders for Ultimate Strength, London, 1971, IABSE, Vol.11, pp. $377 \sim 352,1972$.

9) Abdel-Sayed, G. : Curved Web under Combined Shear and Normal Stress, Proc. of ASCE, ST 3, Vol.99, pp. 511 525, Mar. 1973.

10）三上市蔵・古西和夫・米沢 博：曲げを受ける円筒腹板 パネルの非線形挙動, 土木学会論文報告集, No. 299, pp. 23〜34, 1984 年 7 月.

11) Mikami, I and Furunishi, K. : Nonlinear Behavior of Cylindrical Web Panels, Journal of Engineering Mechanics, ASCE, Vol.110, No.2, pp. 239 251, Feb. 1984.

12）倉西茂・桶渡 茂：曲げを受ける曲線プレートガー ダーのウェブプレートの弾性挙動について, 土木学会論 文報告集, No. 315, pp.1 11, 1981 年 11 月.

13) Hiwatashi, S. and Kuranishi, S. : The Finite Displacement Behavior of Horizontally Curved Elastic I-Section Plate Girders under Bending, Proc. of JSCE, Structural Eng. /Earthquake Eng., Vol.1, No.2, pp. 59 69, Oct. 1984.

14) Mozer, J., Cook, J. and Culver, C. G. : Stability of Curved Plate Girders No. P 3, Carnegie-Mellon University Research Report, Jan. 1973.

15) AASHTO : Guide Specifications for Horizontally Curved Highway Bridges, 1983.

16）中井 博・北田俊行・大南亮一：曲線桁橋腹板の曲げ強 度に関する実験的研究，土木学会論文報告集，No. 340， pp. 227〜236, 1983 年 12 月.

17） 中井 博・北田俊行 · 大南亮一：有限要素法による曲線 桁橋腹板の非線形特性に関する研究, 第 29 回構造工学シ ンポジウム (土木学会), 20, 昭和 58 年 2 月.

18) Bathe, K., Ramm, E. and Wilson, E. L. : Finite Element Formulations for Large Deformation Dynamic Analysis, Inter. Jour. for Numerical Method in Eng. , Vol. 9, pp. 353 386, 1975.

19）中井 博 - 松村駿一郎・吉川 紀 - 北田俊行 · 大南亮一 : 曲線析橋腹板の実績調査, 橋梁と基礎, Vol. 15, No.4, pp. 38 43, 1981 年 5 月.

20) Nakai, H. and Kotoguchi, H. : A study on Lateral Buckling Strength and Design Aid for Horizontally Curved I-Girder Bridges, Proc. of JSCE, No.399, Nov. 1983.

21）日本道路協会 : 道路橋示方書 - 同解説, 丸善, 昭和 55 年 2 月.

22) Maeda, Y. and Okura, I. : Fatigue Strength of Plate 
Girder in Bending Considering Out-of-Plane Deformation, Proc. of JSCE, Structural Eng. /Earthquake Eng., Vol. 1, No.2, pp. 35 45, Oct. 1984.

23) Daniels, J.H., Fisher, J. W. and Yen, B. T. : Fatigue of Curved Steel Bridges Elements; Design Recomendations for Fatigue of Curved Plate Girder and Box Girder Bridges, Final Report, Apr. 1980.

24) Fisher, J. W. : Fatigue and Fracture in Steel Bridges, Case Studies, John Wiley \& Sons, 1984.
25）小松定夫：鋼道路橋の合理的設計へのアプローチ，関西 道路研究会創立 35 周年記念報告書, pp. $187 \sim 215$, 昭和 59 年 12 月.

26) Timoshenko, S. P. and Goodier, J. N. : Theory of Elasticity, Third Edition McGRAW-Hill, 1982.

27）中井 博 - 北田俊行 · 大南亮一：曲げとせん断との組合 せ荷重を受ける曲線桁の強度特性に関する研究, 土木学 会論文報告集, No. 365／I - 3, pp. 380 389, 1985 年 4 月.

(1985.4.5 - 受付) 